\title{
COMPARISON OF SERVICE CHARACTERISTICS OF TWO TOWN'S WWTP
}

\author{
Lubos Jurik', Tatiana Kaletova', Miroslava Sedmakova', Petra Balazova', Andrea Cervenanska' \\ 1 Department of Water Resources and Environmental Engineering, Slovak University of Agriculture in Nitra, \\ Hospodarska 7, 94976 Nitra, Slovakia, e-mail: lubos.jurik@uniag.sk
}

Received: 2017.02.03

Accepted: 2017.03.07

Published: 2017.05.02

\begin{abstract}
The study presents variation of wastewater inflow and its components during a year. We considered a situation with and without precipitation. Two renovated wastewater treatment plants were selected to analyse the available parameters and relation between them. Both wastewater treatment plants served to treat domestic and industrial wastewater with similar characteristics. One of them is only for the town purposes; second one serves for the surrounding villages. The relation between the concentration of pollutants and a flow of wastewater is very low. The correlation and a coefficient of the determination between pollutants were over 0.5 .
\end{abstract}

Keywords: wastewater, wastewater treatment plant, pollutants, inflow, dry weather flow

\section{INTRODUCTION}

In last years a lot of articles about the evaluation of efficiency of the wastewater treatment plants were published [Bauwens 1996, Hospido 2007, Lindtner 2008]. The efficiency of the wastewater treatment plants (WWTP) is not as important as the emission limits in a recipient [Prat 2012, Solvi 2005, Szkarowski 2015, Hubačíková et al. 2015]. The requirement for the appropriate WWTP service is based on accomplishment of specified concentration of parameters at the outflow from the WWTP [Meirlaen 2002]. Those concentrations should suit to Directive $91 / 271 / \mathrm{EEC}$ or the national legislation. Also, the limits have to be specified by the office of water protection. According to a size of the WWTP an amount of the analysis is defined according to the control requirements.

Therefore, calculations of efficiency are utterly theoretical [Rauch 1995]. The requirement defined in directive is too low. The article No. 10 of the directive requires: "Member States shall ensure that the urban waste water treatment plants built to comply with the requirements of Articles 4, 5, 6 and 7 are designed, constructed, operated and maintained to ensure sufficient performance under all normal local climatic conditions. When designing the plants, seasonal variations of the load shall be taken into account." The required efficient is defined in the annex (Table 1), but it is not specified how to solve the seasonal impact. This information is provided for the technology producers as for service to keep the outflow limits.

The values of concentration or a percentage of reduction of parameter is used for the evaluation of the treatment process. We can find presentation of $95 \%$ of reduction in the articles [e.g. Clara et al. 2005, Hamilton et al. 2016], although it is not so important. Much more important are the emission limits after the treatment process.

The achievement of a suitable reduction is also based on the quantity and quality of inflow (raw wastewater). Therefore, we analysed the inflow to two WWTP in the Slovak towns. The design and service of WWTP has to be created according to changing inflow - the quantity and the concentration of wastewater. The knowledge about the conditions of wastewater inflow creation is much more important than the general solution of the pollution reduction [Jurík and Krupová 2010].

The most difficult thing to evaluate the process is usually to obtain adequate information to analyse the creation of inflow. We need to know the construction and dimensions of town's sewage and town's topography. Mainly is the combine sewage systems used in Slovakia and the surrounding states. The storm-water inlets are 
Table 1 Requirements of outflow from wastewater treatment plants [Directive 91/271/EEC]

\begin{tabular}{|c|c|c|}
\hline Parameter & Concentration & $\begin{array}{c}\text { Minimal reduction, } \\
\%\end{array}$ \\
\hline $\mathrm{BOD}_{5}$ & $25 \mathrm{mg} / \mathrm{l} \mathrm{O}_{2}$ & $70-90$ \\
\hline $\mathrm{COD}$ & $125 \mathrm{mg} / \mathrm{O}_{2}$ & 75 \\
\hline $\begin{array}{c}\text { Total undissolved } \\
\text { solids }\end{array}$ & $35 \mathrm{mg} / \mathrm{l}$ & 90 \\
\hline
\end{tabular}

built-up for the sewage systems to drain out the unknown volume of storm and wastewater to a recipient. According to a type of sewage system we have to analyse the creation of quality and the volume of wastewater. Therefore, it is necessary to know the companies with an important production of wastewater, their conditions of production and changes, e.g. during the seasons. If the combined sewage is used, it is also important to know a runoff of rainfall. The runoff of rainfall is related to the shape and the area of the town, the type of the surface, as well as the appropriate determination of design rainfall.

The information about rainfall in the town is almost unavailable, and it is possible to obtain data about daily rainfall. It is necessary to know the design parameters of WWTP to evaluate the inflow. The WWTP are built-up approximately for 30 years in operation and for possible town's development. Therefore, the current load of WWTP could be lower than it is designed.

The knowledge of inflow changes is important mainly for the appropriate design of WWTP, as well as service. The inflow changes are evident during a day, a week or a month. The season has the impact on the variability as well. The inflow change is a result of a group of the factors as climate, a town's size, economic activities in the area and the quality of a water supply. The daily changes are characterized by inflow changes from a minimum to a daily maximum. The inflow minimum occurs usually by night. A monthly inflow maximum is evident usually during the summer months, minimum in winter.

The aim of this paper is to compare the inflow changes and the selected parameters of the wastewater quality during the season with and without rainfalls in two WWTP in Slovakia.

\section{MATERIAL AND METHODS}

Two renovated WWTP of domestic and industrial wastewater were chosen (tab. 2). One of them is only for the town itself; the second one is also for surrounding villages. Information about wastewater flow and its components were used for years 2011-2015, 2014-2015, respectively. The analyses were made by statistical methods in MS Excel.

The combine sewage system with a stormwater inlet is built-up in both towns. Therefore, we presume that no inflow variation would be evident during the season with high precipitation. The problem is that we do not have any information about a capacity of the storm-water inlet. Moreover, the precipitation up to $2 \mathrm{~mm}$ is an interception on the objects, and do not create a surface runoff. Daily precipitation was given by the Slovak Academy of Sciences, Institute of Hydrology. Furthermore, we determine a coefficient of daily variability of inflow which is used for the sewage design.

The first WWTP consists of the mechanical treatment and the wastewater pumping, the biological treatment (an anaerobic reactor, the activation reservoirs, and the chemical coagulation of phosphorus), the tertiary treatment, sludge and the gas management [Balážová and Jurík 2015].

The second one is constructed differently. The WWTP was renovated in 2012, and a part of the old WWTP is still in operation. It is constructed as the mechanical and biological treatment (the cascades of an activation process with sludge regeneration). The first two cascades ( 20 and $25 \%$ of the volume, respectively) are the new ones, the third one ( $55 \%$ of volume) is the main part of the biological treatment [Červeňanská and Jurík 2016].

\section{RESULTS}

\section{The first WWTP - town Galanta}

The input data for analysis were from 2011-2015 years. We obtained data of the daily flow, the daily precipitation and bi-weekly data for biochemical oxygen demanded in 5 days $\left(\mathrm{BOD}_{5}\right)$,

Table 2 Parameters of selected WWTP

\begin{tabular}{|c|c|c|}
\hline & $\begin{array}{c}1^{\text {st }} \text { WWTP } \\
\text { (Galanta) }\end{array}$ & $\begin{array}{c}2^{\text {nd }} \text { WWTP }(\mathrm{L} . \\
\text { Mikulas) }\end{array}$ \\
\hline $\begin{array}{c}\text { Equivalent } \\
\text { inhabitant }\end{array}$ & 45,000 & 126,400 \\
\hline $\begin{array}{c}\text { Dry daily } \\
\text { discharge }\left(\mathrm{Q}_{24}\right)\end{array}$ & $\begin{array}{c}9,703 \mathrm{~m}^{3} / \mathrm{d}(112 \\
\mathrm{l} / \mathrm{s})\end{array}$ & $\begin{array}{c}36,288 \mathrm{~m}^{3} / \mathrm{d}(420 \\
\mathrm{l} / \mathrm{s})\end{array}$ \\
\hline $\begin{array}{c}\text { Real daily average } \\
\text { discharge }\end{array}$ & $43.4 \mathrm{l} / \mathrm{s}$ & $403.47 \mathrm{l} / \mathrm{s}$ \\
\hline
\end{tabular}


dissolved solids (DS), total nitrogen $\left(\mathrm{N}_{\text {tot }}\right)$ and total phosphorus $\left(\mathrm{P}_{\text {tot }}\right)$ of untreated wastewater.

The inflow of wastewater was created by wastewater from the city and rainwater runoff created by the precipitation. Nowadays, the designed inflow is higher than the current one (Fig. 1). The designed inflow was reached only four times in evaluated years; it was lower during other days. The daily average inflow was $43.4 \mathrm{l} / \mathrm{s}$ (min. $21.1 \mathrm{l} / \mathrm{s}$, max. $123.3 \mathrm{l} / \mathrm{s}$ ), and the daily average dry weather inflow was $43.96 \mathrm{l} / \mathrm{s}$ (Fig. 2). The designed inflow was not reached during the dry weather season.

The progress of inflow has similar trend in dry and wet weather. The precipitation has low impact on the WWTP inflow. A coefficient of the determination is also low $\left(\mathrm{R}^{2}=0.1187\right)$, therefore, we cannot predict the wastewater flow. The storm-water inlet should be constructed within the sewage system, but its detailed information is not determined.

A factor 1.4 of the average daily fluctuation is applied to design the sewage systems and WWTP of this size. This factor is suitable for our measurements as the bottom limit, but not as the upper limit. The upper limit was exceeded only a few times in both situations. During the whole season, the factor 2.0 would be also exceeded.

The analysis of wastewater concentration and relation between the particular parameters was

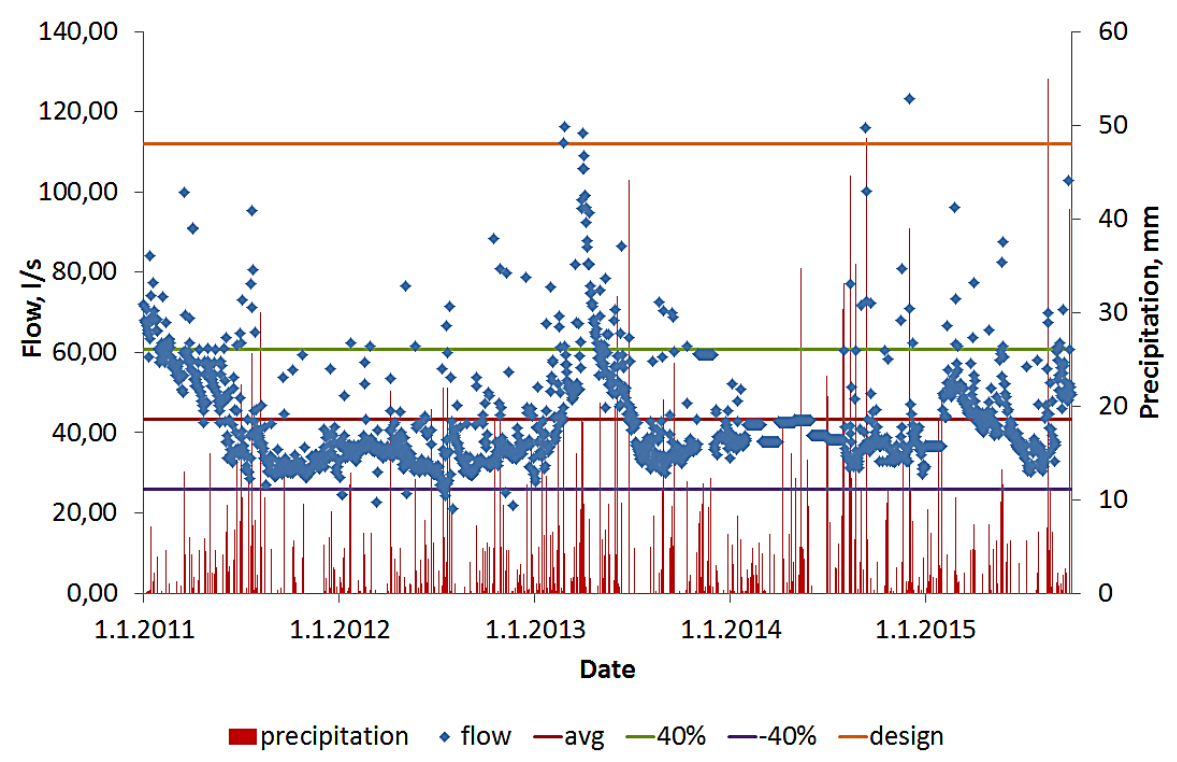

Figure 1. Daily WWTP inflows and daily precipitation - whole season at WWTP Galanta

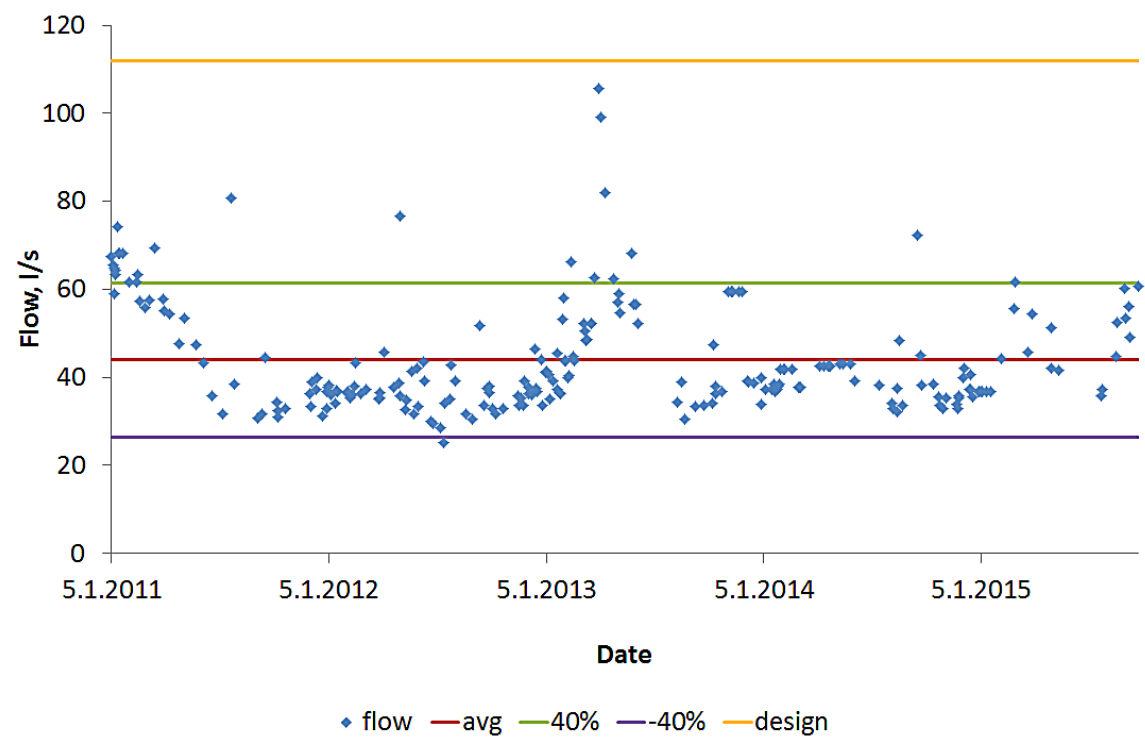

Figure 2. Daily average dry weather flow at WWTP Galanta 
done according to information worked out by the Water Company. The correlation and regression analysis were made separately for the wet and dry weather flow and the whole season; and the descriptive statistics for the dry and wet season.

The concentration of the selected parameters varied during the season (Table 3). The dissolved solids, $\mathrm{BOD}_{5}$ and the flow have the higher range in the wet season, total nitrogen and phosphorus in the dry season. The standard error and a confidence level (95\%) of the parameters are higher in the wet season, except the $\mathrm{P}_{\text {tot }}$.
The correlation and regression analysis show the very low relation (Tab. 4). The higher relations occur during the wet weather flow. The negative correlation (indirect relation) between the parameters is during the dry weather season, as well as between all the parameters and flow.

The high relation is between biochemical oxygen demanded and total nitrogen in all the situations. The correlation over 0.5 occurred between $\mathrm{BOD}_{5} / \mathrm{N}_{\text {tot }}, \mathrm{BOD}_{5} / \mathrm{P}_{\text {tot }}, \mathrm{DS} / \mathrm{N}_{\text {tot }}$ and $\mathrm{N}_{\text {tot }} / \mathrm{P}_{\text {tot }}$ during the wet weather flow. The coefficient of determination is also higher. There is no or indirect relation between the parameters and flow (Fig. 3).

Table 3 The descriptive statistics of the parameters for the dry and wet weather flow at WWTP in Galanta

\begin{tabular}{|l|c|c|c|c|c|c|c|c|c|c|}
\hline & \multicolumn{2}{|c|}{$\mathrm{BOD}_{5}[\mathrm{mg} / \mathrm{l}]$} & \multicolumn{2}{c|}{$\mathrm{DS}[\mathrm{mg} / \mathrm{l}]$} & \multicolumn{2}{c|}{$\mathrm{N}_{\text {tot }}[\mathrm{mg} / \mathrm{l}]$} & \multicolumn{2}{c|}{$\mathrm{P}_{\text {tot }}[\mathrm{mg} / \mathrm{l}]$} & \multicolumn{2}{c|}{$\mathrm{Q}[\mathrm{l} / \mathrm{s}]$} \\
\hline Season & wet & $\mathrm{dry}$ & wet & dry & wet & dry & wet & dry & wet & dry \\
\hline Mean & 198.23 & 179.13 & 689.69 & 743.13 & 49.21 & 47.85 & 6.64 & 9.73 & 51.52 & 41.44 \\
\hline Standard Error & 21.78 & 6.08 & 20.22 & 7.80 & 2.67 & 2.15 & 0.76 & 0.97 & 4.39 & 1.08 \\
\hline Median & 169 & 169 & 693 & 738 & 51.05 & 53 & 5.95 & 6.6 & 43.1 & 37.45 \\
\hline Mode & 178 & 157 & 622 & 702 & 54.6 & 3 & 7.3 & 6.9 & 39.2 & 36.7 \\
\hline Standard Deviation & 111.0 & 55.41 & 103.1 & 71.10 & 13.61 & 19.54 & 3.89 & 8.85 & 22.38 & 9.81 \\
\hline Range & 410.6 & 259.8 & 500 & 452 & 50.4 & 78.7 & 20.1 & 36.1 & 93.6 & 46.8 \\
\hline Minimum & 79.4 & 70.2 & 490 & 598 & 25.6 & 0 & 2.3 & 3.1 & 29.7 & 28 \\
\hline Maximum & 490 & 330 & 990 & 1050 & 76 & 78.7 & 22.4 & 39.2 & 123.3 & 74.8 \\
\hline $\begin{array}{l}\text { Confidence Level } \\
\text { (95\%) }\end{array}$ & 44.85 & 12.10 & 41.64 & 15.53 & 5.50 & 4.27 & 1.57 & 1.93 & 9.04 & 2.15 \\
\hline
\end{tabular}

Table 4 The correlation analysis of the selected parameters during the whole year and the wet seasons at WWTP in Galanta (correlation coefficient)

\begin{tabular}{|c|c|c|c|c|c|c|c|c|}
\hline & \multicolumn{2}{|c|}{$\mathrm{BOD}_{5}$} & \multicolumn{2}{|c|}{ DS } & \multicolumn{2}{|c|}{$\mathrm{N}_{\text {tot }}$} & \multicolumn{2}{|c|}{$P_{\text {tot }}$} \\
\hline Season & wet & whole & wet & whole & wet & whole & wet & whole \\
\hline Dissolved solids & 0.032 & 0.173 & - & - & - & - & - & - \\
\hline $\mathrm{N}$ total & 0.491 & 0.723 & 0.139 & 0.596 & - & - & - & - \\
\hline $\mathrm{P}$ total & 0.021 & 0.698 & 0.117 & 0.262 & 0.698 & -0.607 & - & - \\
\hline Flow & -0.380 & -0.369 & -0.261 & -0.352 & -0.584 & -0.524 & -0.328 & 0.171 \\
\hline
\end{tabular}
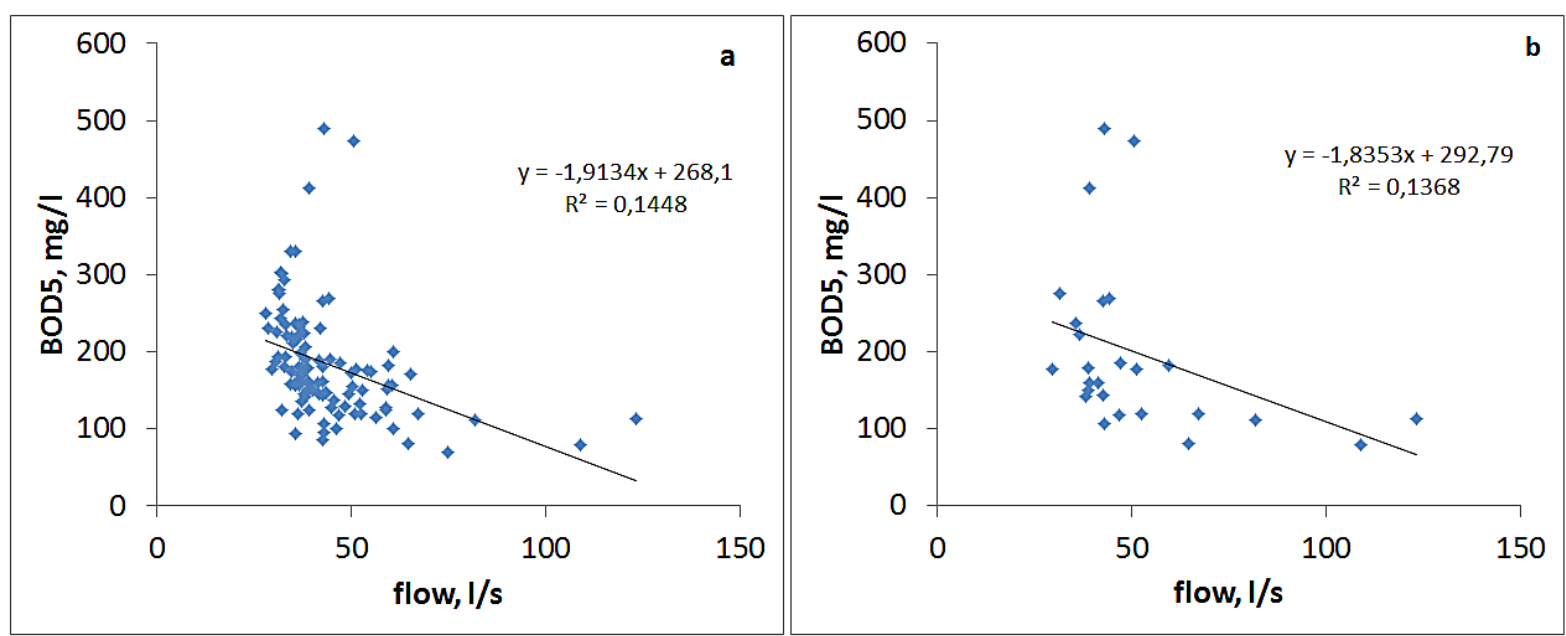

Figure 3. Regression of BOD5 and flow: a) whole season, b) dry weather season at WWTP Galanta 


\section{The second WWTP - Liptovský Mikuláš town}

The analysis of the wastewater parameters and flow were made according to information for 2014 and 2015. We received data for biochemical oxygen demand in 5 days, the dissolved and suspended solids (SS), total nitrogen, total phosphorus, chemical oxygen demand (COD).

The current flow is similar to the designed one (Fig. 4). The factor 1.4 of average daily fluctuation of wastewater flow was applied as well. The situation was similar to the previous WWTP. The bottom limit was not reached, but the upper limit was exceeded by several times. In such a case, the more appropriate factor would be 1.7. That limit would be reached or exceeded only 3 times. The coefficient of determination is below
$0.1 \mathrm{in}$ all cases. Therefore, there is no relation between precipitation and inflow to WWTP.

The concentration of the selected pollutants varied during the years 2014-2015 (Tab. 5). The ranges, as well as the other statistical parameters were higher in 2015 than in 2014 year, except the SS. The concentrations of the pollutants are higher than in the first WWTP, especially the maximum values.

The relation between the parameters and flow is indirect and low (Tab. 6). The concentration of pollutants does not dependent on the flow. The relation between the particular pollutants is positive. Particularly between $\mathrm{COD}$ and $\mathrm{BOD}_{5}$ the relation is high, it reaches over 0.94 (Fig. 6). Those parameters are closely connected with one another.

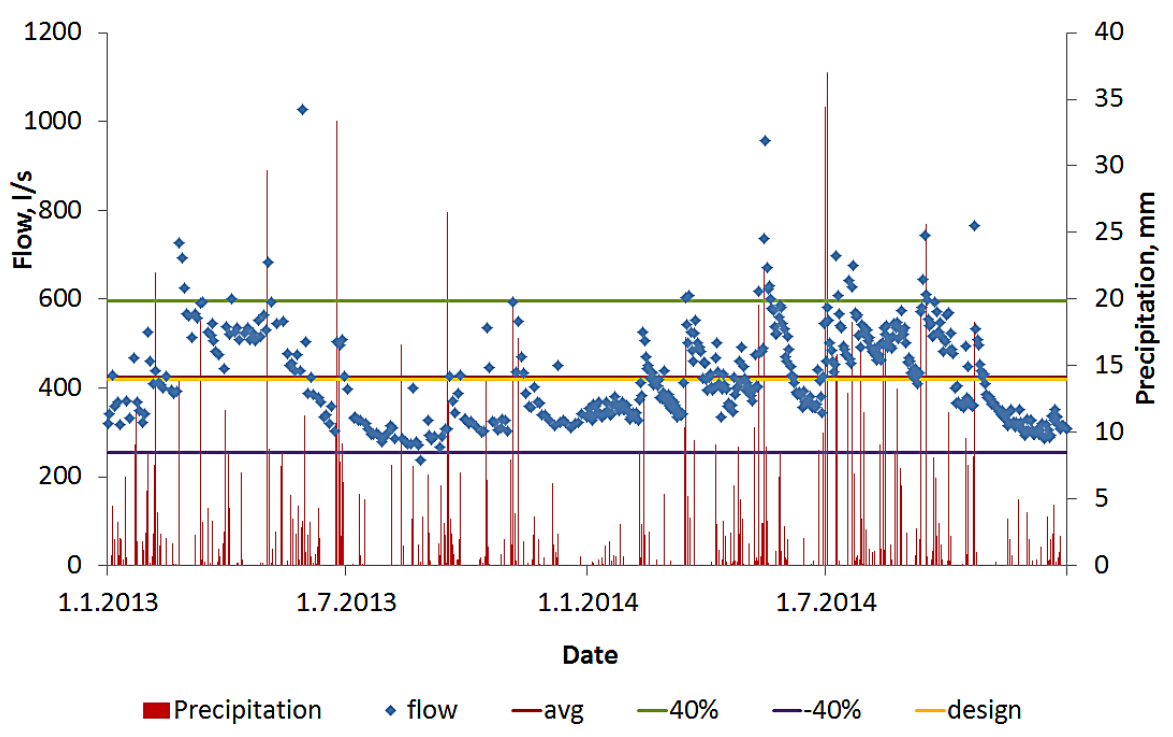

Figure 4. Daily flow and daily precipitation - whole season at WWTP Liptovský Mikuláš

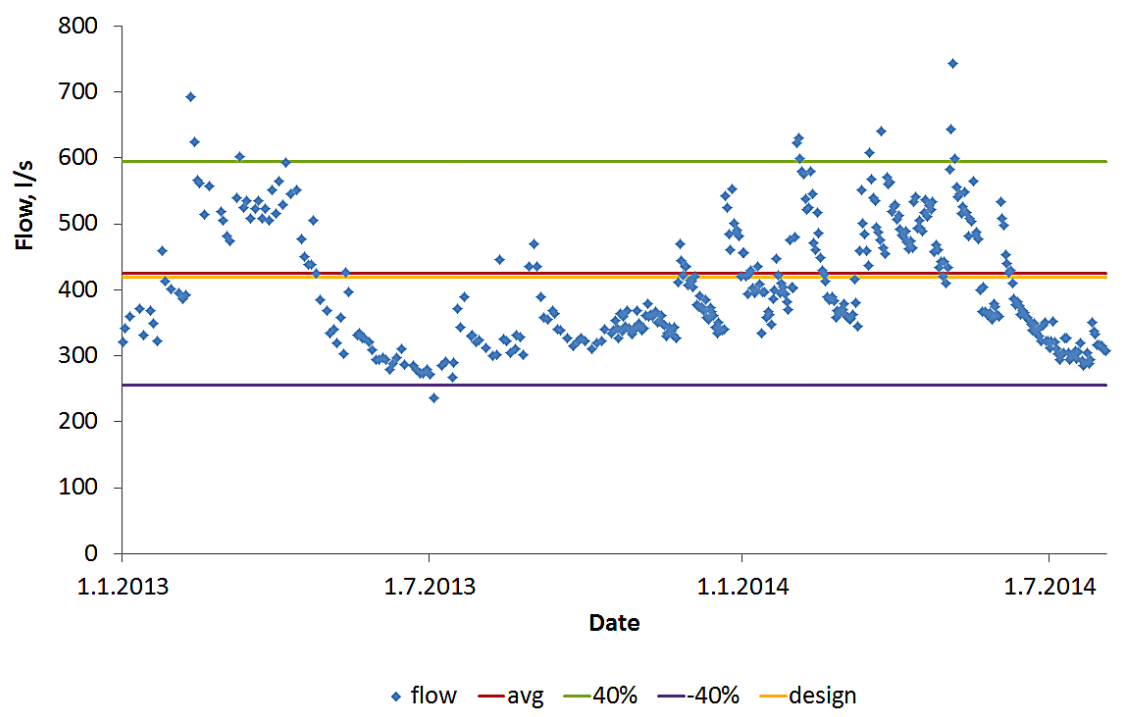

Figure 5. Daily average dry weather flow at WWTP Liptovský Mikuláš 
Table 5. The average, maximum, minimum and the range of pollutants concentration in 2014 and 2015 WWTP at Liptovský Mikuláš

\begin{tabular}{|c|c|c|c|c|c|c|c|}
\hline \multicolumn{2}{|c|}{ Inflow } & BOD $_{5}[\mathrm{mg} / \mathrm{l}]$ & $\mathrm{COD}[\mathrm{mg} / \mathrm{l}]$ & $\mathrm{DS}[\mathrm{mg} / \mathrm{l}]$ & $\mathrm{SS}[\mathrm{mg} / \mathrm{l}]$ & $\mathrm{N}_{\text {tot }}[\mathrm{mg} / \mathrm{l}]$ & $\mathrm{P}_{\text {tot }}[\mathrm{mg} / \mathrm{l}]$ \\
\hline \multirow{3}{*}{2015} & Average & 585.2 & 1168.4 & 615.6 & 814.1 & 42.0 & 3 \\
\cline { 2 - 9 } & Max & 2569.2 & 3340.6 & 3507.7 & 1773.5 & 101.6 & 9.9 \\
\cline { 2 - 9 } & Min & 153.3 & 408.8 & 100.6 & 393.7 & 0 & 0 \\
\hline \multicolumn{2}{|c|}{ Range } & 2415.9 & 2931.8 & 3407.1 & 1379.8 & 101.6 & 9.9 \\
\hline \multirow{3}{*}{2014} & Average & 384 & 776.7 & 431.2 & 1023 & 44.9 & 3.2 \\
\cline { 2 - 9 } & Max & 1366.8 & 1567.6 & 1915.4 & 2400.8 & 67.4 & 6.1 \\
\cline { 2 - 9 } & Min & 0 & 219 & 68.2 & 445.7 & 19.7 & 1.5 \\
\hline \multicolumn{2}{|c|}{ Range } & 1366.8 & 1348.6 & 1847.2 & 1955.1 & 47.7 & 4.6 \\
\hline
\end{tabular}

Table 6. The correlation analysis of the selected parameters during the whole season WWTP in Liptovský Mikuláš (correlation coefficient)

\begin{tabular}{|c|c|c|c|c|c|c|c|}
\hline \multicolumn{2}{|c|}{} & $\mathrm{BOD}_{5}$ & $\mathrm{COD}$ & $\mathrm{SS}$ & $\mathrm{DS}$ & $\mathrm{N}_{\text {tot }}$ & $\mathrm{P}_{\text {tot }}$ \\
\hline \multirow{2}{*}{2015} & Flow & -0.546 & -0.534 & -0.532 & -0.396 & -0.179 & -0.110 \\
\cline { 2 - 9 } & $\mathrm{BOD}_{5}$ & & 0.941 & 0.831 & 0.387 & 0.069 & 0.075 \\
\hline \multirow{2}{*}{2014} & Flow & -0.362 & -0.273 & -0.097 & -0.052 & -0.346 & -0.460 \\
\cline { 2 - 9 } & $\mathrm{BOD}_{5}$ & & 0.741 & 0.759 & 0.271 & 0.542 & 0.635 \\
\hline
\end{tabular}
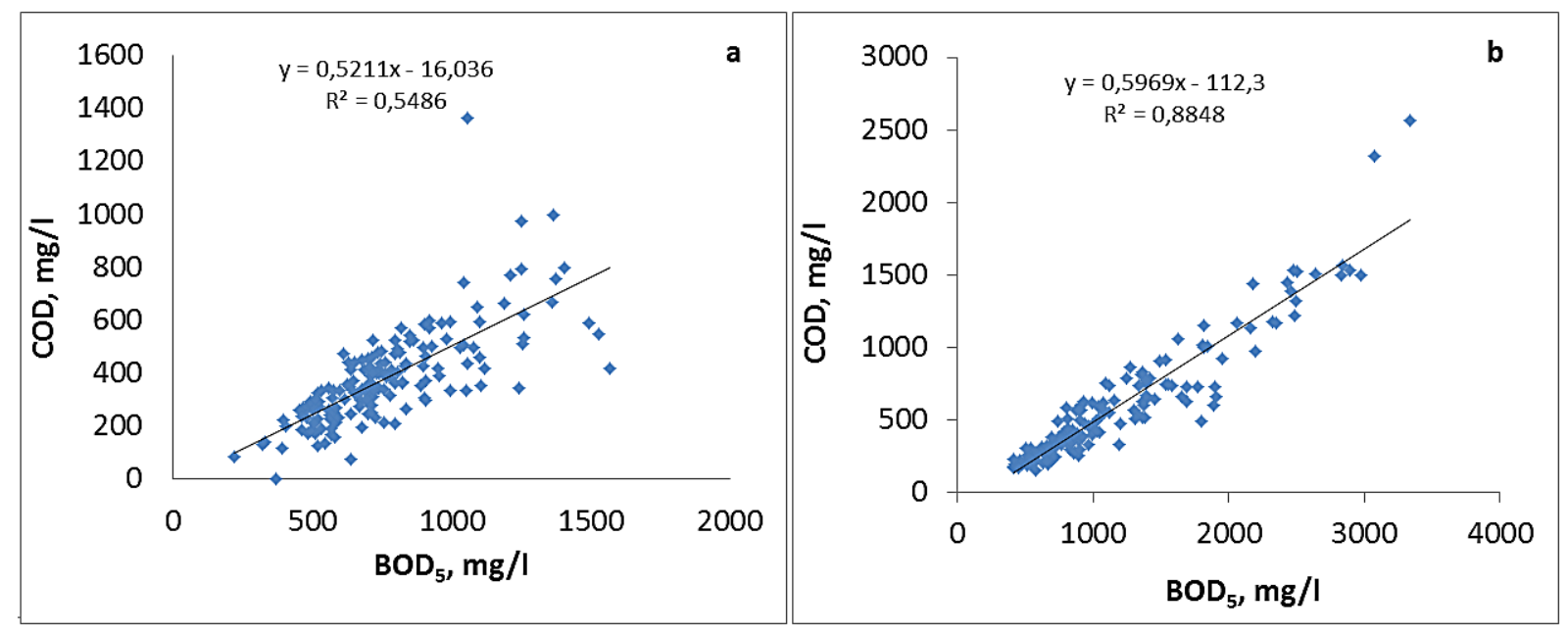

Figure 6. Regression of BOD $_{5}$ and COD; a) 2014, b) 2015 at WWTP Liptovsky Mikulas

\section{CONCLUSION}

The main finding of the article; there is no relation between the rainfall and inflow to the WWTP in both towns. The process of wastewater creation is very coincidental, and it is influenced by many factors. The concentration of pollutants and flow of wastewater is different in both WWTP. Moreover, the relation between pollutants concentration varied. The relation between the parameters is very low too. The only relation is the relation between biochemical and chemical oxygen demand. Other parameters are created chaotically, and the permanent control of those processes is necessary in all WWTP.

\section{REFERENCES}

1. Balážová, P., Jurík, L. 2015. Hodnotenie reálnych a prevádzkových parametrov čistiarne odpadových vôd Galanta. Proc. Študentská vedecká konferencia FZKI 2015, 118-124.

2. Bauwens, W., Vanrolleghem, P., Smeets M. 1996. An evaluation of the efficiency of the combined sewer-wastewater treatment system under transient conditions. Wat. Sci. Tech., 33(2), 199-208.

3. Červeňanská, A., Jurík, L., 2016 Zhodnotenie prevádzky čistiarne odpadových vôd v meste Liptovský Mikuláš. Proc. Študentská vedecká konferencia FZKI 2016, 28.

4. Clara, M. Kreuzinger, N. Strenn, B. Gans, O. Kroiss H. 2005. The solids retention time - a suit- 
able design parameter to evaluate the capacity of wastewater treatment plants to remove micropollutants. Water Research, 39(1), 97-106.

5. DIRECTIVE 91/271/EEC - Council Directive 91/271/EEC of 21 May 1991 concerning urban waste-water treatment, Official Journal L 135 , 30/05/1991 P. 0040 - 0052

6. Hamilton, L.A., Tremblay, L.A., Northcott, G. L., Boake, M. Lim, R. P. 2016. The impact of variations of influent loading on the efficacy of an advanced tertiary sewage treatment plant to remove endocrine disrupting chemicals. Science of The Total Environment, 560-561, 101-109.

7. Hospido, A., Moreira, M.T., Feijoo, G. 2007. A Comparison of Municipal Wastewater Treatment Plants for Big Centres of Population in Galicia (Spain). International Journal of Life Cycle Assessment, 13(1), 57-64.

8. Hubačíková, V., Oppeltová, P., Navrátilová, L. 2015. Influence of recreation on water quality on the bílý stream watershed. Proc. Public Recreation and Landscape Protection - With Man Hand in Hand!, 117-122.

9. Jurík, L', Krupová, K. 2010. Hodnotenie návrhu a účinnosti ČOV v malých obciach v čiastkovom povodí Horného Hrona. Proc. Odpadové vody
2010: zborník prednášok 6. bienálnej konferencie s medzinárodnou účast'ou, 360-365.

10. Lindtner, S., Schaar, H., Kroiss, H. 2008. Benchmarking of large municipal wastewater treatment plants treating over 100,000 PE in Austria. Water science and technology, 57(10), 1487-1493.

11. Meirlaen, J. 2002. Immission-based real time control of the integrated urban wastewater system. Faculteit Landbouwkundige en Toegepaste Biologische Wetenschappen. Gent, University of Gent.

12. Prat, P., Benedetti, L. et al. 2012. Model-based knowledge acquisition in environmental decision support system for wastewater integrated management. Water Science and Technology, 65(6), 1123-1129.

13. Rauch, W., Harremoës, P. 1995. Integrated urban water quality management. Proc. 9th Forum for Applied Biotechnology.

14. Solvi, A.-M., Benedetti, L. et al. 2005. Integrated urban catchment modelling for a sewer treatment - river system. Proc. 10th International Conference on Urban Drainage.

15. Szkarowski, A S., Janta-Lipiñska, S., 2015. Sustainable sewage management in rural areas. Rocznik Ochrona Srodowiska, 17(1), 576-584 